\title{
In situ time-resolved Raman spectroelectrochemical study of aniline polymerization at platinum and gold electrodes
}

Regina Mažeikienè,

Gediminas Niaura,

Albertas Malinauskas ${ }^{*}$

Department of Organic Chemistry, Center for Physical Sciences and Technology,

Sauletekio Ave. 3, 10257 Vilnius, Lithuania
A comparative in situ time-resolved Raman spectroelectrochemical study on aniline polymerization at platinum, smooth gold, and roughened gold electrodes was performed with $785 \mathrm{~nm}$ laser excitation. Under the constant anodic current density electrolysis performed at the platinum electrode, the intensity of Raman bands grows continuously reaching a steady state within 8-10 min. At the smooth gold electrode, the maximum intensity is observed in a few or few tens of seconds, and appears to be ca. 1.5 orders of magnitude higher than for the platinum one. At the roughened gold electrode, again, a fast growth of intensity is observed, being ca. 3 orders higher than for the platinum one. After a prolonged electrolysis of ca. $150-200 \mathrm{mC} / \mathrm{cm}^{2}$, the intensities for all three electrodes appear to be of a similar intensity. The results obtained show a strong surface enhancement of Raman spectra at the gold electrode, a very strong at the roughened gold one, and no enhancement at the platinum electrode at the beginning of electrooxidation, turning into a regular Raman scattering at a prolonged electrolysis, sufficient for the formation of a stable layer of polyaniline at the electrode surface.

Keywords: polyaniline, Raman spectroscopy, spectroelectrochemistry, electrooxidation, electropolymerization

\section{INTRODUCTION}

Raman spectroscopy presents a very useful tool for elucidation of various aspects related to synthesis and properties of electroactive and conducting polymers. Previous classic works, dated back by a few decades, helped in determining the structure of then new materials like polypyrrole and polyaniline, as well as their redox properties, doping and electric conductance mechanisms. More recently, Raman spectroscopy tends to turn into an usual and widely used technique for the study of novel materials and composites based on conducting polymers.

\footnotetext{
*Corresponding author. Email: albertas.malinauskas@ftmc.lt
}

Many problems related to the chemical structure and polymerization mechanisms could be solved with the use of Raman spectroscopy. The electropolymerization mechanism has been suggested based on FTIR and Raman spectroscopy for the multifunctional material consisting of polypyrrole (PPy) films embedded with cobalt nanoparticles [1]. The resulting composite material presents superparamagnets at room temperature, whose magnetization could be modified by changing of preparation variables. With the help of Raman spectroscopy, the participation of definite functional groups during the electrochemical preparation of a novel poly(4-amino-2,1,3-benzothiadiazole) film has been evidenced [2]. The covalent grafting of $\mathrm{N}$-substituted carboxyl polyaniline onto graphene oxide, 
resulting in the production of nanorod structures suitable for supercapacitor applications, has been confirmed with Raman spectroscopy [3]. With the use of Raman spectroscopy, the mechanism for electropolymerization of pyrrole at the zinc coated surface has been elucidated, consisting of the initial formation of a zinc oxide and hydroxide layer, replaced consecutively by a zinc tartrate layer, followed by the three-dimensional growth of polypyrrole onto it [ [].

Raman spectroscopy appears useful in the study of the electronic structure of conducting polymers. In the study of polysulfonic acid doped polyaniline (PANI), electrochemical potential-dependent Raman bands related to PANI, and potential-independent bands related to polyacids were observed, and an increased content of cation radicals in these composites, as compared to $\mathrm{HCl}$-doped PANI films, was deduced [5]. A strong interaction between the quinoid type structures of PANI with carbon nanostructures via pi-pi stacking was detected by Raman spectroscopy for the nanocomposites of PANI and the carbon nanostructures like graphene and multiwall carbon nanotubes [6]. A somewhat related effect on the surface enhancement of Raman spectra has been achieved by sorption of copper ions onto a polypyrrole film, followed by electrochemical reduction resulting in the polypyrrole-copper nanocomposite [帄. Characteristic features for polyaniline covalently bound to the gold electrode surface due to the defined surface-chain bonding and the ordered polymer structure have been observed by near-infrared Raman spectroscopy [8].

Basically, Raman spectroscopy presents sophisticated technique and requires intricate equipment. Therefore, most of the works done with Raman spectroscopy on conducting and electroactive polymers deal with a limited number of variable parameters used in obtaining Raman spectra. As with Raman spectroelectrochemistry, one of the most important parameters is the electrochemical potential. This potential drives the redox state of a conducting polymer bound to the electrode surface. Correspondingly, the characteristic structural changes taking place within the polymer layer could be detected spectrometrically, and important information regarding the structure and its changes could be drawn. At the same time, scarce works on the time-evolvement of Raman spectra during electrochemical transformations have been done. Obviously, the implementation of time-resolved Raman spectroelectrochemistry requires even more sophisticated equipment, and other experimental difficulties as well. Some of our previous works directly addressed timedependent Raman studies on the electrochemical stability and decomposition of polyaniline [9], self-doped polyaniline [10], and poly (N-methylaniline) [11]. Also, a kinetic study with time-resolved Raman spectrometry has been done on the electrocatalytic oxidation of selected solution species at the polyaniline modified electrode [12]. Recently, we have successfully applied Raman spectroscopy for the in situ kinetic study of the chemical oxidative polymerization of aniline and N-methylaniline by a dichromate anion [13, 14]. To the best of our knowledge, no in situ comparative kinetic Raman spectroelectrochemical study on electropolymerization of aniline and related species on different substrates has been done yet. In the present work, we aimed at a direct in situ study of the electrochemical oxidation of aniline at different electrodes with time resolved Raman spectroscopy.

\section{EXPERIMENTAL}

Commercially available analytical or reagent grade chemicals were used. A BASi-Epsilon model potentiostat (Bioanalytical Systems Inc., USA) was used in all electrochemical experiments. Platinum and gold flat circular electrodes of ca. $5 \mathrm{~mm}$ in diameter, press-fitted into a Teflon rod, as a working electrode, platinum wire as a counter electrode, and a potassium chloride saturated $\mathrm{Ag} / \mathrm{AgCl}$ reference electrode were used. All potential values reported below refer to this reference electrode.

Before each experiment, the working electrode was cleaned for $1 \mathrm{~h}$ in a Piranha solution (a mixture of 30\% hydrogen peroxide and concentrated sulfuric acid, 3:1 by vol.), and ultrasonicated for $2 \mathrm{~min}$ in an ethanol and water mixture. For the preparation of a roughened gold electrode $\mathrm{Au}$ (SERS) the surface of the working electrode has been roughened electrochemically in a $0.1 \mathrm{M} \mathrm{KCl}$ solution by cycling for 50 cycles within the potential scan limits of -0.3 and $1.4 \mathrm{~V}$ at a potential scan rate of $0.2 \mathrm{~V} / \mathrm{s}$.

Electrooxidation of aniline was performed in a solution containing $0.05 \mathrm{M}$ of aniline and $0.5 \mathrm{M}$ of sulfuric acid. Two methods for electropolymerization of aniline were used. Following the electropolymerization at a constant controlled current, an anodic current density of $0.357 \mathrm{~mA} / \mathrm{cm}^{2}$ was applied to the platinum or the smooth (unroughened) gold electrodes, whereas for the roughened gold electrode an anodic current density of $0.536 \mathrm{~mA} / \mathrm{cm}^{2}$ was applied, because of 1.5 times higher surface area of the latter.

The arrangement for Raman spectroscopy was same as in our previous work 15]. Raman spectroelectrochemical experiments were done in a cylinder-shaped three electrode moving cell, arranged with a platinum or a gold working electrode (as described above), a platinum wire counter electrode, and a $\mathrm{KCl}$ saturated $\mathrm{Ag} / \mathrm{AgCl}$ reference electrode. Raman spectra were recorded using an Echelle type spectrometer RamanFlex 400 (PerkinElmer, Inc.) equipped with a thermoelectrically cooled up to $-50^{\circ} \mathrm{C} C \mathrm{CD}$ camera and a fiber-optic cable for excitation and collection of the Raman spectra. The 785-nm beam of the diode laser was used as the excitation source. The $180^{\circ}$ scattering geometry was employed. The laser power at the sample was restricted to $30 \mathrm{~mW}$ and the beam was focused to a $200 \mu \mathrm{m}$ diameter spot on the electrode. The integration time was $100 \mathrm{~s}$. The working electrode was placed at approx. $3 \mathrm{~mm}$ distance from the cell window. In order to reduce photo- and thermoeffects, and a possible degradation of the resulting polyaniline layer by the incident light as well, the cell holder was moved periodically with respect to the laser beam at ca. $15-25 \mathrm{~mm} / \mathrm{s}$ with the help of custom built equipment [16]. 


\section{RESULTS AND DISCUSSION}

In general, two different techniques were used in the present work for the electrochemical oxidation of aniline - galvanostatic anodic electrolysis at a controlled anodic current density, and electrolysis at a controlled potential. Figure 11 shows the Raman spectra obtained from a platinum electrode following the galvanostatic electrolysis. During the first $1 \mathrm{~min}$ of the electrolysis, almost no changes in the Raman spectra above the noise level are observed. Later, few bands appear distinguishable, and a well-resolved spectrum is obtained after a few minutes of electrolysis. The analysis of Raman spectra observed reveals electropolymerization of aniline to proceed, followed by the formation of oligo- or polyaniline. The bands observed in the Raman spectra are summarized and assigned in Table 1. Basically, three spectral ranges

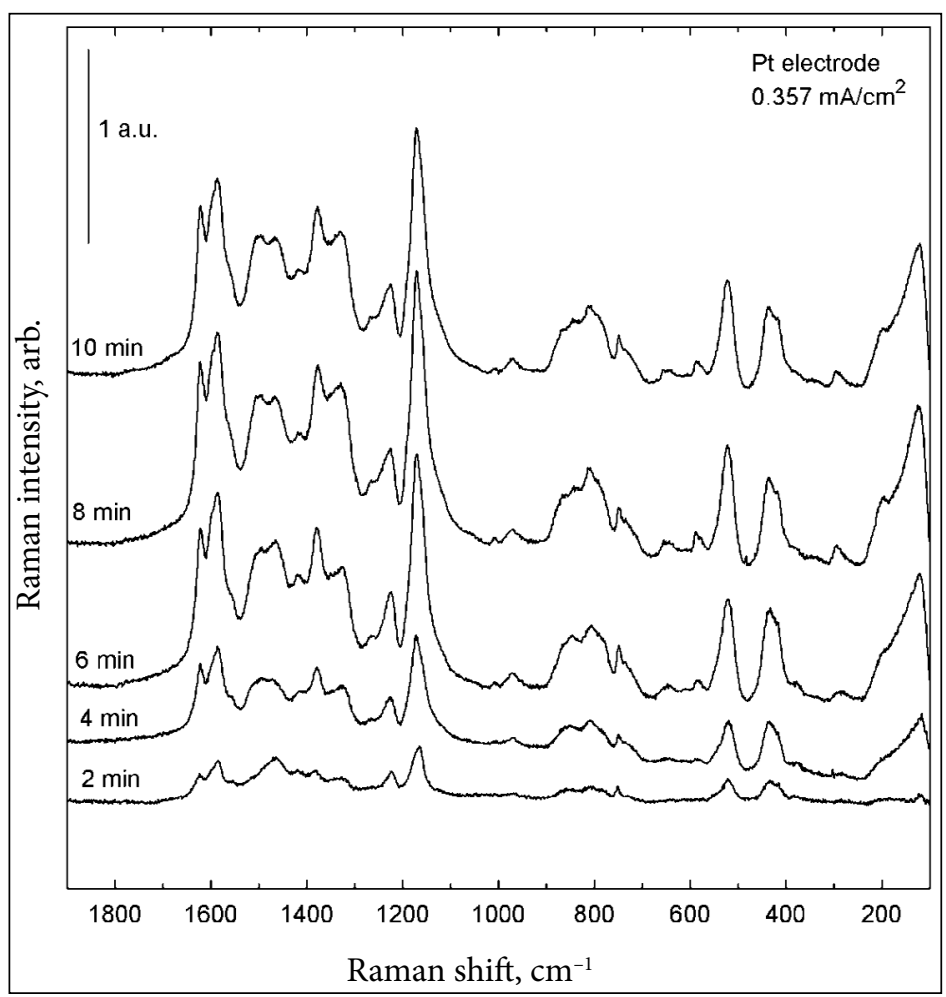

Fig. 1. Raman spectra obtained from the platinum electrode at different time moments ranging from 2 to 10 min (as indicated) during electrolysis performed in a galvanostatic manner at a controlled anodic current density of $0.357 \mathrm{~mA} / \mathrm{cm}^{2}$ in a solution containing $0.5 \mathrm{M}$ of sulfuric acid and $0.05 \mathrm{M}$ of aniline. Spectra were excited by $785 \mathrm{~nm}$ laser beam

Ta ble. Characterization of vibration bands of Raman spectra for electropolymerization of aniline at different electrodes (wavenumbers are given in $\mathrm{cm}^{-1}$ )

\begin{tabular}{|c|c|c|c|}
\hline Pt electrode & Au electrode & Au (SERS) electrode & Assignments \\
\hline $1622 \mathrm{~s}$ & $1627 \mathrm{~s}$ & $1627 \mathrm{~s}$ & $\mathrm{C}-\mathrm{C}$ stretching in $\mathrm{B}(8 \mathrm{a})$ \\
\hline $1586 \mathrm{~s}$ & $1584 \mathrm{~s}$ & $1582 \mathrm{~s}$ & $\mathrm{C}=\mathrm{C}$ stretching in $\mathrm{Q}(8 \mathrm{a})$ \\
\hline $1500 m$ & $1508 \mathrm{~m}$ & $1507 m$ & $\mathrm{C}=\mathrm{N}$ stretching in emeraldine (imine sites) \\
\hline $1467 m$ & & & $\mathrm{C}-\mathrm{C}$ stretching of phenazine structures \\
\hline \multicolumn{4}{|l|}{$1417 w$} \\
\hline $1377 \mathrm{~m}$ & $1374 s$ & $1372 v s$ & \\
\hline \multirow[t]{2}{*}{$1330 m$} & 1334sh & $1332 \mathrm{sh}$ & $\mathrm{C} \sim \mathrm{N}+$ stretching in polaronic form \\
\hline & $1274 w$ & $1273 w$ & $\mathrm{C}-\mathrm{N}$ stretching \\
\hline \multirow[t]{2}{*}{$1225 \mathrm{~m}$} & $1233 w$ & $1233 w$ & C-N stretching in emeraldine (amine form) \\
\hline & 1184vs & $1186 s$ & $\mathrm{C}-\mathrm{H}$ bending in leucoemeraldine salt (9a) \\
\hline $1171 \mathrm{vs}$ & & $1175 s$ & $\mathrm{C}-\mathrm{H}$ bending in emeraldine $(9 \mathrm{a})$ \\
\hline \multicolumn{4}{|l|}{$1008 v w$} \\
\hline $971 w$ & $980 \mathrm{vw}$ & $979 \mathrm{vw}$ & B deformation $(1+12)$ \\
\hline $863 \mathrm{sh}$ & $868 w$ & $869 w$ & B deformation (1) \\
\hline \multicolumn{4}{|l|}{$841 \mathrm{sh}$} \\
\hline $813 m$ & $815 \mathrm{~m}$ & $817 \mathrm{~m}$ & Amine deformation ( $\mathrm{C}-\mathrm{N}-\mathrm{C}$ bending) \\
\hline $750 w$ & $723 w$ & $724 w$ & Imine deformation ( $\mathrm{C}-\mathrm{N}=\mathrm{C}$ bending) \\
\hline
\end{tabular}




\begin{tabular}{c|c|c|c}
\hline Table (continued) & \\
\hline Pt electrode & Au electrode & Au (SERS) electrode & Assignments \\
\hline $648 \mathrm{w}$ & $651 \mathrm{vw}$ & $651 \mathrm{vw}$ & Ring deformation (6b) \\
\hline $590 \mathrm{w}$ & $593 \mathrm{w}$ & $591 \mathrm{w}$ & Ring deformation (6b) \\
\hline $523 \mathrm{~m}$ & $518 \mathrm{~m}$ & $517 \mathrm{~m}$ & $\begin{array}{c}\text { Out-of-plane deformation of } \mathrm{B}, \\
\text { amine in-plane deformation }\end{array}$ \\
\hline $437 \mathrm{~m}$ & & & Out-of-plane deformation of B \\
\hline $418 \mathrm{sh}$ & $415 \mathrm{~m}$ & \\
\hline $294 \mathrm{w}$ & & & \\
\hline $197 \mathrm{sh}$ & $191 \mathrm{sh}$ & $193 \mathrm{sh}$ & \\
\hline $124 \mathrm{~m}$ & $120 \mathrm{~m}$ & $120 \mathrm{~m}$ &
\end{tabular}

Assignments are based on the known data [17-21]. The numbers given in parentheses (1), (1+12), (6b), (8a), and (9a) refer to Wilson's notation of aromatic species vibration modes. Abbreviations used: $B$, benzene type ring; $Q$, quinone type ring; , bond intermediate between a single and a double bond; vs, very strong; $s$, strong; m, middle; w, weak; vw, very weak; sh, shoulder

should be considered, next to a big number of the bands located outside of these regions [17-21]:

1. $1100-1210 \mathrm{~cm}^{-1}$, where bending vibrations of a $\mathrm{C}-\mathrm{H}$ bond are evident. For the platinum electrode, a very strong band centered around $1171 \mathrm{~cm}^{-1}$ appears dominating within this range.

2. $1210-1520 \mathrm{~cm}^{-1}$ range with the most characteristic stretch vibrations of a single $\mathrm{C}-\mathrm{N}$, a double $\mathrm{C}=\mathrm{N}$, and an intermediate $\mathrm{C} \sim \mathrm{N}$ bonds. As for the platinum electrode, a mid-intense band at $1225 \mathrm{~cm}^{-1}$ is observed, representing the $\mathrm{C}-\mathrm{N}$ (amine form) stretching in an emeraldine form of PANI, along with a mid-intense band at $1330 \mathrm{~cm}^{-1}$, characteristic most probably of the $\mathrm{C} \sim \mathrm{N}^{+}$ stretching in a polaronic form, and a $1500 \mathrm{~cm}^{-1}$ band, characteristic of the $\mathrm{C}=\mathrm{N}$ (imine form) stretching in an emeraldine form.

3. $1520-1650 \mathrm{~cm}^{-1}$ range with very characteristic C-C single bond stretch vibrations in benzene fragments, and $\mathrm{C}=\mathrm{C}$ double bond stretch vibrations of quinone fragments of PANI. In the case of the Pt electrode, these are a strong band at $1622 \mathrm{~cm}^{-1}$ for benzene type, and a strong band at $1586 \mathrm{~cm}^{-1}$ for quinone type rings of the PANI structure.

Nearly all bands observed at the platinum electrode grow proportionally in their intensities by progression in electrolysis, except for the band(s) located around $1500 \mathrm{~cm}^{-1}$,

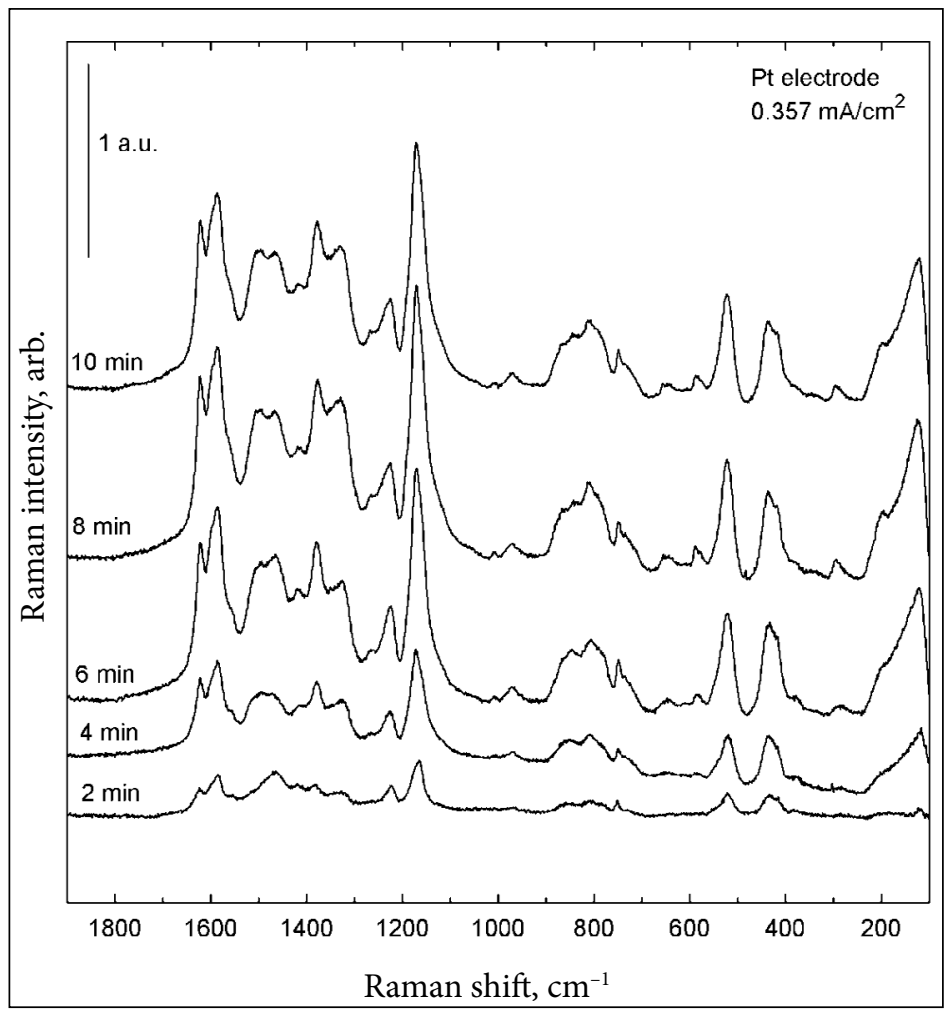

Fig. 2. Same as in Fig. 1, obtained from the smooth gold electrode at different time moments ranging from 5 to $600 \mathrm{~s}$ (as indicated) 
where the number of bands varies during the first $5 \mathrm{~min}$ of electrolysis, and then stabilizes. This growth proceeds up to about $10 \mathrm{~min}$ of the electrolysis time at the conditions specified, whereas later it appears less regularly because of some secondary processes, like the obvious accumulation of a high amount of soluble coloured oligomeric species in a solution adjacent to the electrode, also probably of mechanical instability of a thick layer of electrodeposited polyaniline, followed by its peeling, etc.

A totally different behaviour is observed at the gold electrode, as depicted in Fig. 2. Basically, it should be first noted that the Raman spectra obtained are related qualitatively to those characteristic of the platinum electrode. Again, a very strong band at $1184 \mathrm{~cm}^{-1}$ is observed, corresponding to $\mathrm{C}-\mathrm{H}$ bendings in a leucoemeraldine form (Table 1). As compared to the platinum electrode, the position of $\mathrm{C}-\mathrm{N}$ single bond stretchings appears to be slightly (by $8 \mathrm{~cm}^{-1}$ ) shifted towards higher wavenumbers, whereas significant changes were

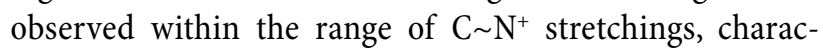
teristic of a polaronic form of polyaniline, around 1400$1300 \mathrm{~cm}^{-1}$. Previously, we deduced a few kinds of polarons to present in polyaniline, and manifesting themselves within this spectral region [18]. Also, the position of the $\mathrm{C}=\mathrm{N}$ stretching of an emeraldine form (imine sites of PANI) appears shifted by $8 \mathrm{~cm}^{-1}$ to higher wavenumbers. A slight shift in frequency by -2 and $5 \mathrm{~cm}^{-1}$ should be noted for strong Raman bands characteristic of $\mathrm{C}=\mathrm{C}$ and $\mathrm{C}-\mathrm{N}$ stretchings of quinone and benzene fragments, respectively (Table 1).

The most striking difference between electrooxidation of aniline at these two background electrodes is the difference in spectral intensities, and the time-resolved evolution of Raman spectra as well. The following differences and features should be noted:

1. At the platinum electrode, the maximum intensity of the Raman spectrum is observed at about 8-10 min of electrolysis, whereas it takes only about $15 \mathrm{~s}$ to reach the maximum intensity at the gold electrode.

2. At the platinum electrode, the intensity increases gradually during the first few minutes of electrolysis, and stabilizes in 5-10 min, whereas a fast initial growth during $10-15 \mathrm{~s}$ is followed by a gradual decrease in intensity and its stabilization after 5-10 min.

3. The final intensity of Raman spectra, obtained after a prolonged electrolysis, is of the same order of magnitude for both types of electrodes.

The differences observed could be interpreted as follows. By starting the electrolysis, oxidation of aniline proceeds leading to cation radicals that react with aniline monomer molecules resulting in the production of bluecoloured oligo- and polyanilines. A part of these products, especially those formed at the beginning of the electrooxidation process (presumably low molecular mass oligoanilines), are soluble and diffuse from the electrode surface into the bulk of the solution, whereas another part (presumably oligo- or polyanilines of higher molecular mass) deposits at the electrode surface forming a dense layer of polyaniline. As a result, at least three contributions to the resulting Raman spectra should be considered: i) surface enhancement from the gold electrode surface, ii) resonance scattering from soluble free diffusing coloured species, mostly of oligoanilines, and iii) resonance scattering from a deposited layer at the electrode surface. Most probably, the spectra obtained at the platinum electrode present the resonance spectra from a deposited layer of the end product of electrooxidation - polyaniline. For the platinum electrode, almost no spectrum has been observed in the first few tens of seconds, where intense spectra have been observed at the gold electrode, thus, almost no increments neither from surface enhancement nor from resonance scattering of soluble oligoanilines are observed. After a few minutes of electrolysis, a stable and relative thick layer of polyaniline appears deposited at the platinum electrode, and the corresponding Raman spectrum belongs obviously to this layer (Fig. 1).

As opposite to platinum, the most intense changes in $\mathrm{Ra}$ man spectra at the gold electrode are observed in the first few tens of seconds of electrolysis. This shows the origin of these initial spectra from surface enhancement (SERS). There should also be an increment from resonance scattering from soluble oxidation products, however, this possibility could be nearly excluded because in this case this increment should be observed even at platinum what is not a case. Noteworthy, the maximum intensity of spectra from the gold electrode obtained after 10-15 s of electrolysis appears to be roughly one order of magnitude higher than the maximum intensity of spectra from the platinum electrode after 5-10 min of electrolysis (cf. Figs. 1 and 2). This confirms very probably the different origin of Raman spectra for these two electrodes, being surface enhanced spectra from a thin adsorbed layer of initial products of electooxidation for gold, and resonance spectra from a thick layer of polyaniline deposited at platinum. Accordingly, slightly shifted (by few $\mathrm{cm}^{-1}$ ) Raman bands observed within the three said regions, except for that of $\mathrm{C}=\mathrm{C}$ stretchings in quinone sites, when turning from the platinum to the gold electrode (Table 1), represent most probably surface enhanced spectra from a monolayer of the oxidation products of polyaniline. A thick layer of polyaniline, as that deposited at platinum, is represented by slightly lower wavenumbers (Table 1). Also, an important difference between these two sets of spectra should be noted. As it is well known, polarons are very important in electric conductance of polyaniline and related conducting polymers. In Raman spectra, polarons are represented as stretching vibrations of the intermediate (between a single and a double) bond $\mathrm{C} \sim \mathrm{N}^{+}$around $1330 \mathrm{~cm}^{-1}$. Previously we discussed the presence of different kinds of polarons, as it could be deduced from Raman spectra [18]. For the platinum electrode, a well resolved mid-intense band related to polarons is observed at $1330 \mathrm{~cm}^{-1}$ (Fig. 1). For the gold electrode, however, only shoulder of low intensity around $1334 \mathrm{~cm}^{-1}$ is observed 


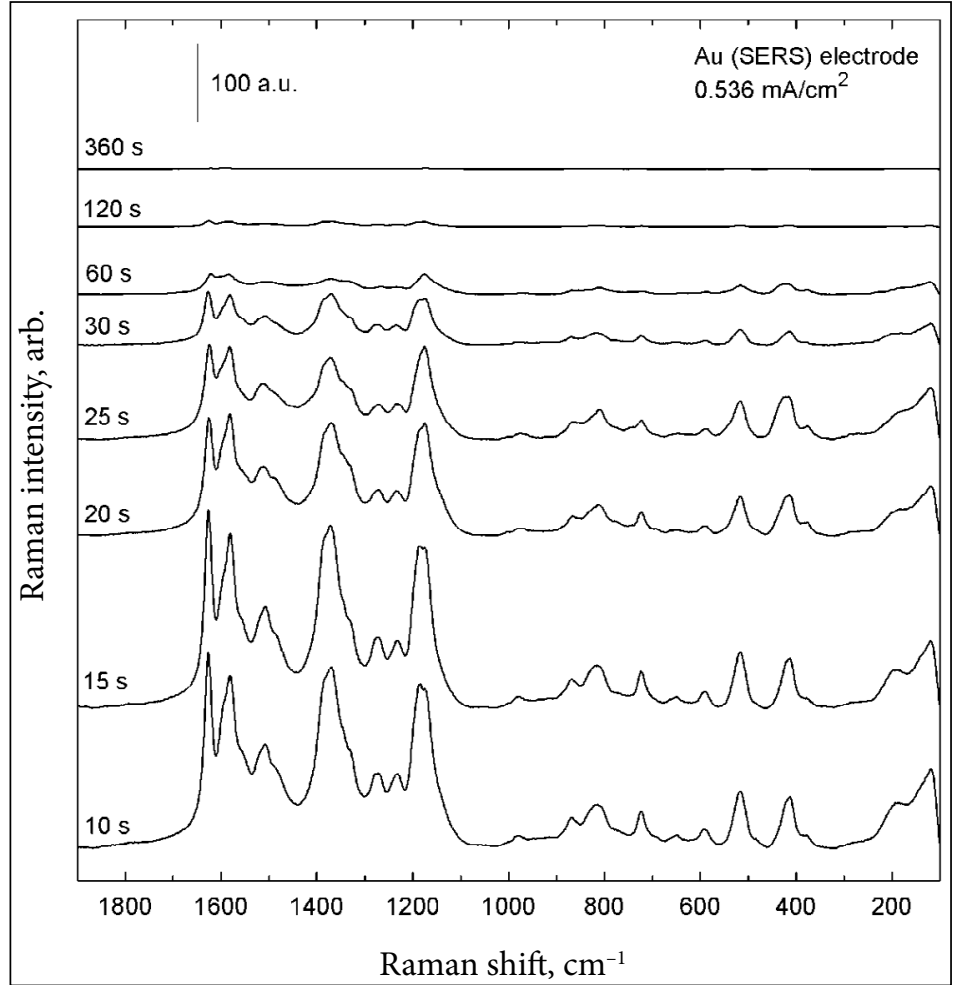

Fig. 3. Same as in Fig. 1, obtained from the roughened gold electrode $\mathrm{Au}$ (SERS) at different time moments ranging from 10 to $360 \mathrm{~s}$ (as indicated) at a controlled anodic current density of $0.536 \mathrm{~mA} / \mathrm{cm}^{2}$ that could be assigned to the $\mathrm{C} \sim \mathrm{N}^{+}$bond stretchings, i.e. to polarons (Fig. 2). Clearly, the polarons could be simply generated within the thick layer of polyaniline deposited at platinum, whereas no or low content of polarons should present in a monolayer of polyaniline adsorbed at the gold electrode.

Figure 3 shows the time-resolved Raman spectra for electrooxidation of aniline under the same conditions as in Figs. 1 and 2, however, performed at the specially roughened gold electrode, $\mathrm{Au}$ (SERS) electrode, well suitable for obtaining of surface enhanced spectra. Three differences for this electrode, as compared to the unroughened gold, should be mentioned:

1. The Raman bands observed, regarding their number, positions, and relative intensities (as compared to each other), are closely related to those observed at the smooth gold electrode (Table 1).

2. The intensities of Raman bands are by an order of magnitude higher than for the smooth gold electrode, and about two orders of magnitude higher as compared to the platinum electrode (cf. vertical bars representing relative intensity in Figs. 1, 2, and 3).

3. The most intense spectra are observed at the shortest reaction time of about 5-15 s (Fig. 3). This is a much faster growth of intensity as compared to that of the platinum, and even faster than for the smooth gold electrodes. After about $15 \mathrm{~s}$ of electrolysis, the intensity starts to drop similarly to the smooth electrode.

4. After a prolonged electrolysis, the intensity of Raman spectra stabilizes at a level, nearly coinciding to those, characteristic of the smooth gold and platinum electrodes.
The said pecularities for all three types of electrodes used could be well illustrated by changes in a relative intensity for a selected band centered around $1174 \mathrm{~cm}^{-1}$, as depicted in Fig. 4. Instead of using a time scale, an electric (anodic) charge, passed during electrooxidation process, has been chosen as an abscissa for Fig. 4. A huge difference in intensity at the start of electrooxidation between the plat-

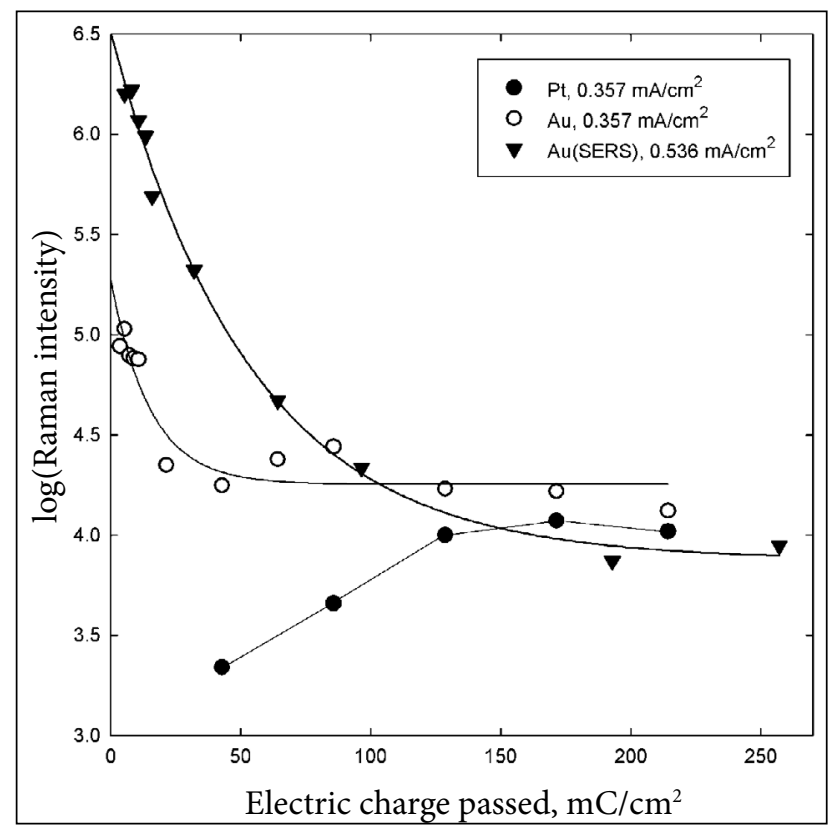

Fig. 4. Dependence of the relative intensity for a $1174 \mathrm{~cm}^{-1}$ Raman band on the electric (anodic) charge passed during the controlled current density electrolysis for the platinum, smooth gold, and roughened gold electrodes (as indicated) 
inum and the roughened gold electrodes is seen, reaching 3 orders of magnitude. Also, an increase in the intensity for the platinum elctrode, and a decrease for both types of the gold electrodes are well seen, as well as a convergence of intensities after a sufficient high electric (anodic) charge (over $150 \mathrm{mC} / \mathrm{cm}^{2}$ ) is passed.

These observations clearly show that both types of the gold electrodes are capable for surface enhancement of Raman spectra during a continuous electrooxidation of aniline. In this respect, the roughened gold electrode shows higher enhancement as compared to that of the smooth gold electrode. At the platinum electrode, no surface enhancement is observed. At a prolonged electrolysis, when a layer of the reaction product, polyaniline, appears deposited at all types of electrodes used, correspondingly, normal or resonance Raman spectra from thick layers of the deposit are observed.

Another set of experiments relates to electrooxidation at a controlled electrode potential. For this, a relatively low potential of $0.8 \mathrm{~V}$ has been chosen that enables to generate coloured products of aniline oxidation at relatively mild conditions. Figure 5 shows the Raman spectra obtained both from roughened and smooth gold electrodes when applying a controlled potential electrolysis at time intervals of $1 \mathrm{~min}$. Again, qualitatively the spectra are closely related to those observed at a constant current electrolysis, and only minor changes in band positions could be detected. The most interesting observations relate to time-dependent changes in the intensities of spectra. For the roughened gold electrode $\mathrm{Au}(\mathrm{SERS})$, a very fast initial increase in intensity was observed in the first few minutes of electrolysis, reaching the intensity maximum in 1-2 min. After that, the intensity drops by an order of magnitude in $5 \mathrm{~min}$. For the smooth gold electrode, a slower growth of spectral intensity is observed. The intensity reaches the maximum in about $3 \mathrm{~min}$, and then drops to a lower value. The maximum intensity for the smooth gold electrode appears to be about 5-8 times lower as compared to that of the $\mathrm{Au}$ (SERS) electrode.

From this experimental set, again, the surface enhancement mechanism of Raman spectra at both types of gold electrodes could be deduced. Under mild conditions used, at a relatively low electrolysis potential of $0.8 \mathrm{~V}$, almost no stable layer of polyaniline is deposited during the experiment in $5 \mathrm{~min}$, thus, the spectra observed originate from the adsorbed layers of oxidation species. Obviously, the intensity of spectra from the roughened electrode appears

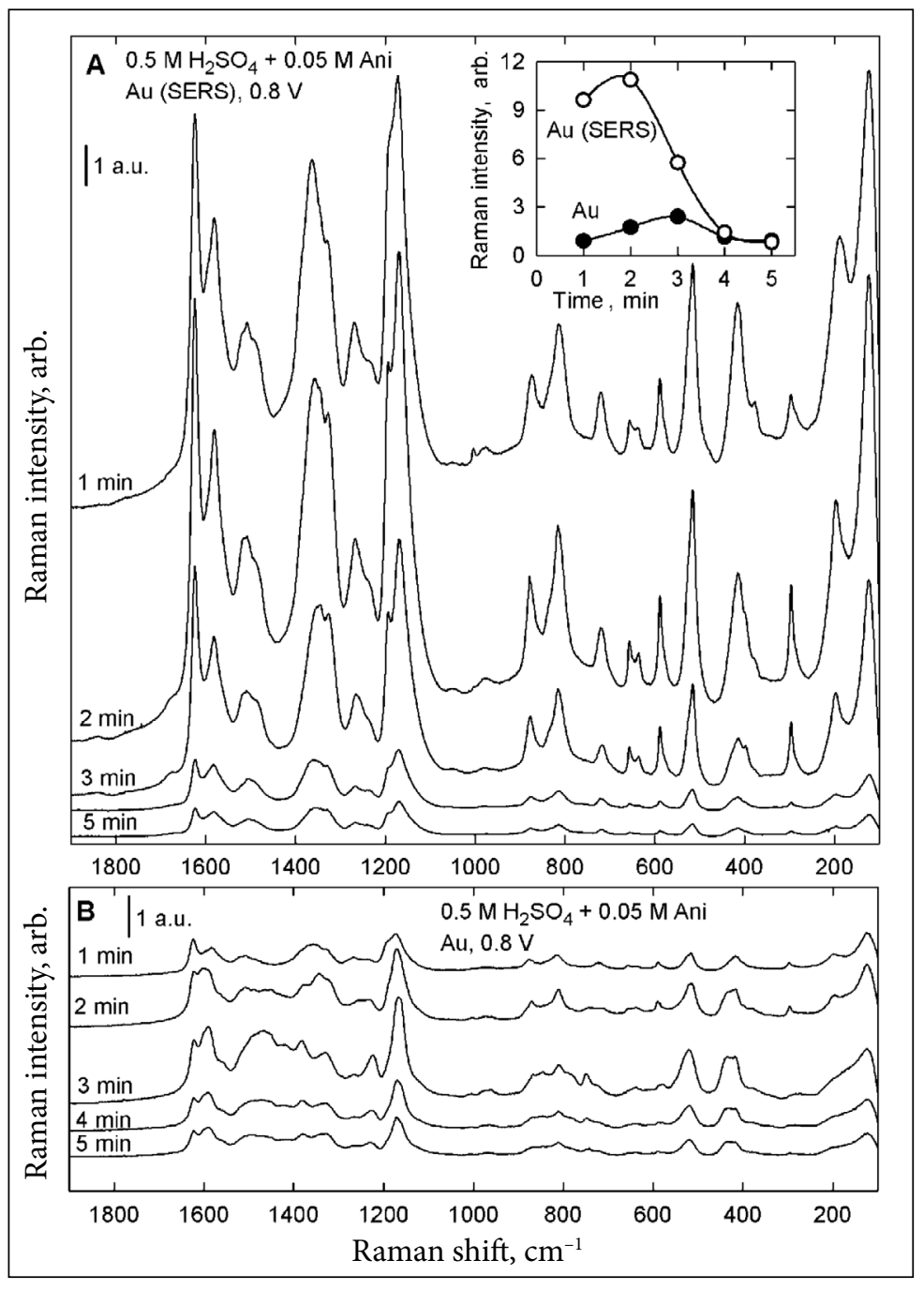

Fig. 5. Raman spectra obtained from Au (SERS) (panel A) and smooth Au (panel B) electrodes upon anodic electrolysis performed for 1 to 5 times (as indicated) at a controlled potential of $0.8 \mathrm{~V}$ at time intervals of $1 \mathrm{~min}$ in a solution containing $0.5 \mathrm{M}$ of sulfuric acid and $0.05 \mathrm{M}$ of aniline. An inset in panel A shows time-dependent changes in intensity for both types of electrodes 
much higher than from the smooth electrode. Also, some qualitative observations from the spectra obtained could be made. When analysing the ratio of intensities for the Raman bands centered around $1627 \mathrm{~cm}^{-1}$ and $1582 \mathrm{~cm}^{-1}$, it is seen that it changes in the course of electrolysis. For the Au(SERS) electrode, the first band prevails initially over the second one in intensity, whereas closely related intensities for these two bands are observed after 5 min of electrolysis. Even more, the same initial ratio of intensities appears to be reversed for the smooth gold electrode (Fig. 5). The related tendencies regarding the time-dependence of the intensity ratio for these two Raman bands could be observed for both types of the gold electrodes even for electrolysis at a constant current density as well, as it is seen in Figs. 2 and 3. In a mechanistic sense, this means a higher relative content of benzene type rings in the structure of reaction products at the beginning of electrooxidation, and an increasing relative content of quinone rings by progressing electrolysis.

Received 14 February 2018 Accepted 1 March 2018

\section{References}

1. M. Gao, L. Y. Lu, X. G. Xu, Z. Yao, Y. Jiang, Electrochim. Acta, 228, 522 (2017).

2. G. Broncova, T. V. Shishkanova, M. Dendisova, M. Clupek, D. Kubac, P. Matejka, Chem. Pap., 71, 359 (2017).

3. J. L. Zhang, J. Gao, Q. Song, et al., Electrochim. Acta, 199, 70 (2016).

4. N. Sheng, M. Ueda, T. Ohtsuka, Prog. Organ. Coat., 76, 328 (2013).

5. A. A. Nekrasov, O. L. Gribkova, O. D. Iakobson, I. N. Ardabievskii, V. F. Ivanov, A. V. Vannikov, Chem. Pap., 71, 449 (2017).

6. A. Petrovski, P. Paunovic, R. Avolio, et al., Mater. Chem. Phys., 185, 83 (2017).

7. I. Chikouche, A. Sahari, A. Zouaoui, S. Tingry, Can. J. Chem. Eng., 93, 1076 (2015).

8. A. Blacha-Grzechnik, R. Turczyn, M. Burek, J. Zak, Vib. Spectrosc., 71, 30 (2014).

9. R. Mažeikienè, G. Niaura, A. Malinauskas, Polym. Degrad. Stab., 93, 1742 (2008).
10. R. Mažeikienè, A. Statino, Z. Kuodis, G. Niaura, A. Malinauskas, Electrochem. Commun., 8, 1082 (2006).

11. R. Mažeikiene, G. Niaura, A. Malinauskas, J. Solid State Electrochem., 11, 923 (2007).

12. R. Mažeikienè, G. Niaura, A. Malinauskas, Electrochim. Acta, 51, 5761 (2006).

13. R. Mažeikienè, G. Niaura, A. Malinauskas, Spectrochim. Acta, Part A, 106, 34 (2013).

14. R. Mažeikienė, G. Niaura, A. Malinauskas, J. Mol. Struct., 1139, 333 (2017).

15. R. Mažeikienė, G. Niaura, A. Malinauskas, Spectrochim. Acta, Part A, 181, 200 (2017).

16. G. Niaura, A. K. Gaigalas, V. L. Vilker, J. Raman Spectrosc., 28, 1009 (1997).

17. R. Mažeikiene, V. Tomkute, Z. Kuodis, G. Niaura, A. Malinauskas, Vib. Spectrosc., 44, 201 (2007), and references cited therein.

18. G. Niaura, R. Mažeikienė, A. Malinauskas, Synth. Met., 145, 105 (2004).

19. M. Trchová, Z. Morávková, M. Bláha, J. Stejskal, Electrochim. Acta, 122, 28 (2014).

20. M. Trchová, Z. Morávková, J. Dybal, J. Stejskal, ACS Appl. Mater. Interfaces, 6, 942 (2014).

21. I. Šeděnková, M. Trchová, J. Stejskal, Polym. Degrad. Stab., 93, 2147 (2008).

Regina Mažeikienè, Gediminas Niaura, Albertas Malinauskas

IN SITU RAMANO SPEKTROELEKTROCHEMINIS

ANILINO POLIMERIZACIJOS ANT PLATINOS IR AUKSO ELEKTRODŲ TYRIMAS

Santrauka

Atlikti palyginamieji in situ Ramano spektroelektrocheminiai anilino polimerizacijos ant platinos, lygaus aukso ir pašiurkštinto aukso elektrodų tyrimai, naudojant $785 \mathrm{~nm}$ lazerio sužadinimo spinduliuotę. Kontroliuojamo anodinès srovès tankio sąlygomis ant platinos elektrodo stebètas spektrų intensyvumo augimas per pirmąsias 8-10 min. Ant lygaus aukso ir šiurkštinto aukso elektrodų didžiausias intensyvumas stebimas po kelių dešimčių sekundžių. Ant lygaus aukso elektrodo pasiekiamas viena ar dviem dydžių eilèmis, o ant šiurkštinto aukso elektrodo - trimis dydžių eilèmis didesnis spektrų intensyvumas, palyginti su platinos elektrodu. 